\title{
Effects of Casein Hydrolysate Ingestion on Thermoregulatory Responses in Healthy Adults during Exercise in Heated Conditions: A Randomized Crossover Trial
}

\author{
Yasuyuki Sakata ${ }^{1}$, Chikako Yoshida ${ }^{2}$, Yuka Fujiki ${ }^{2}$, Yutaka Matsunaga ${ }^{1}$, Hirohiko Nakamura ${ }^{1}$, \\ Takashi Shimizu ${ }^{1}$, Yasuhiro Takeda ${ }^{1}$ and Tatsuro Amano ${ }^{2, *}$ \\ 1 Wellness \& Nutrition Science Institute, Morinaga Milk Industry Co., Ltd., Zama, Kanagawa-Pref. 252-8583, \\ Japan; ys-sakata@morinagamilk.co.jp (Y.S.); y_matsunaga@idaten.c.u-tokyo.ac.jp (Y.M.); \\ hi_nakam@morinagamilk.co.jp (H.N.); t_simizu@morinagamilk.co.jp (T.S.); \\ ya_taked@morinagamilk.co.jp (Y.T.) \\ 2 Laboratory for Exercise and Environmental Physiology, Faculty of Education, Niigata University, Niigata, \\ Niigata-Pref. 950-2181, Japan; chariiiiiin@gmail.com (C.Y.); yuka.fujiki28@gmail.com (Y.F.) \\ * Correspondence: amano@ed.niigata-u.ac.jp; Tel.: +81-25-262-7161
}

Received: 6 February 2020; Accepted: 22 March 2020; Published: 24 March 2020

check for updates

\begin{abstract}
Food ingestion has been shown to affect thermoregulation during exercise, while the impact of protein degradant consumption remains unclear. We investigated the effects of casein hydrolysate ingestion on thermoregulatory responses during exercise in the heat. In a randomized, placebo-controlled, double-blind, crossover trial, five men and five women consumed either $5 \mathrm{~g}$ of casein hydrolysate or placebo. Thirty minutes after ingestion, participants cycled at $60 \% \mathrm{VO}_{2} \max$ until voluntary exhaustion wearing a hot-water $\left(43^{\circ} \mathrm{C}\right)$ circulation suit. Exercise time to exhaustion, body core temperature, forearm sweat rate, and forearm cutaneous vascular conductance did not differ different between the conditions. However, chest sweat rate and mean skin temperature increased upon casein hydrolysate ingestion compared with placebo during exercise. Increased chest sweat rate upon casein hydrolysate ingestion was associated with elevated sudomotor sensitivity to increasing body core temperature, but not the temperature threshold for initiating sweating. A positive correlation was found between chest sweat rate and plasma total amino acid concentration during exercise. These results suggest that casein hydrolysate ingestion enhances sweating heterogeneously by increasing peripheral sensitivity of the chest's sweating mechanism and elevating skin temperature during exercise in the heat. However, the physiological link between plasma amino acid concentration and sweat rate remains unclear.
\end{abstract}

Keywords: casein hydrolysate; sweat rate; body temperature; thermoregulation; exhaustion; aerobic exercise; heat

\section{Introduction}

Heat stress attenuates aerobic exercise performance due to impairment of integrative physiological mechanisms [1,2] including thermoregulatory impairments that result in hyperthermia [3,4] and/or high skin temperature $[5,6]$ during exercise. Several factors potentially affect core body temperature (Tco) and skin temperature independent of exercise-induced heat production. For example, food ingestion has been shown to elevate Tco associated with an increase in postprandial energy expenditure $[7,8]$ which delays Tco threshold for thermoregulatory cutaneous vasodilation during exercise [9]. The type of nutrients also influences postprandial energy expenditure and possibly Tco since a greater 
energy consumption has been reported after protein intake compared with an equivalent amount of carbohydrate ingestion through encouraging protein synthesis and mitochondrial enzymatic activity [10,11]. Differences in protein source may also affect postprandial energy expenditure through the differences in amino acid compositions and its absorption kinetics [12]. Studies have reported that peptides included in casein hydrolysate $(\mathrm{CH})$ show faster absorption kinetics relative to those of amino acids [13]. This is also evidenced by the fact that the ingestion of $\mathrm{CH}$ induces a greater energy expenditure, probably due to enhanced protein synthase and a promotion of mitochondrial enzyme activity than those of equivalent composition of amino acids $[14,15]$. Overall these previous studies imply that proteins consumed before exercise, especially protein hydrolysate such as $\mathrm{CH}$, may influence thermoregulatory responses during exercise. However, to the best of our knowledge, there is limited available literature in this area of research.

Oral consumption of branched-chain amino acids (BCAA), tyrosine, or arginine prior to exercise do not influence Tco, skin temperature, skin blood flow, and sweat rate estimated from exercise-induced body mass loss as well as endurance exercise performance in the heat [16-18]. These previous studies suggest that amino acid consumption does not alter thermoregulatory responses and exercise performance in the heat. On the other hand, intravenous infusion of a mixture of 20 amino acids, which are found in proteins, increased Tco and delayed Tco thresholds for sweating and cutaneous vasodilation in resting heated humans [19], indicating a suppressive modulation for physiological heat loss regulation [20]. The precise reasons for the observed discrepancies between these previous studies regarding the effects of amino acid ingestion/infusion on human thermoregulation are unknown. However, they might be related to the differences in the methodology employed (e.g., exercise vs. passive heating, oral consumption vs. intravenous infusion, and whole body sweat loss vs. continuous local sweat rate measurement). Nevertheless, these observations cannot be translated into the potential effects of $\mathrm{CH}$ ingestion since $\mathrm{CH}$ could elevate Tco more than of amino acid ingestion because of potentially greater postprandial energy expenditure in $\mathrm{CH}$ ingestion [14]. Consequently, the influence of $\mathrm{CH}$ ingestion on thermoregulatory responses in the heat requires further research.

The present study investigated the effect of $\mathrm{CH}$ ingestion on thermoregulatory responses during exercise in the heat (exercise wearing a hot-water circulating perfusion garment). In a preliminary test, we investigated plasma amino acid concentrations after $\mathrm{CH}$ ingestion under a resting normothermic condition wearing a $34^{\circ} \mathrm{C}$ water circulating suit to determine the timing of $\mathrm{CH}$ ingestion before exercise. In the main experiment, we tested a hypothesis that $\mathrm{CH}$ ingestion before exercise would elevate Tco and suppress heat loss responses evidenced by an elevation of Tco threshold for initiating heat loss during exercise.

\section{Materials and Methods}

\subsection{Ethical Approval}

The present study was approved by the human ethical committee of Niigata University, Niigata, Japan (2017-3-008) and conformed to the standards set by the latest version of the Declaration of Helsinki. The study protocol was registered at the University Hospital Medical Information Network (UMIN) clinical trial registry (ID: UMIN000030145). All participants provided verbal and written informed consent before participating in the study.

\subsection{Study Design}

To determine the timing of $\mathrm{CH}$ ingestion prior to the exercise, we measured plasma amino acid concentration after $\mathrm{CH}$ ingestion under resting normothermic conditions (preliminary test). In this preliminary test, we also evaluated thermoregulatory variables to explore the potential influence of $\mathrm{CH}$ intake at rest. Then, we investigated the effect of $\mathrm{CH}$ ingestion on thermoregulatory responses and exercise tolerance under heated conditions (main experiment). All experiments were performed in a double-blind, placebo-controlled, randomized, crossover manner. Randomization was performed by 
the permuted block method (block size of four) and was stratified by gender using SAS ver. 9.4 (SAS Institute Inc., Cary, NC, USA). All trials were conducted between November 2017 and December 2017 at Niigata University, Niigata, Japan.

\subsection{Participants}

Ten healthy adults (five men and five women) participated in the preliminary and main experiments, respectively. Age, height, and body weight were $21.4 \pm 0.8$ years, $167.7 \pm 3.7 \mathrm{~cm}$, and $59.8 \pm 7.4 \mathrm{~kg}$ in the preliminary test and $21.3 \pm 0.8$ years, $166.7 \pm 4.4 \mathrm{~cm}$, and $62.0 \pm 4.7 \mathrm{~kg}$ in the main experiment, respectively. Maximum oxygen uptake $\left(\mathrm{VO}_{2} \mathrm{max}\right)$, which was measured only in the main experiment, was $35.2 \pm 8.2 \mathrm{~mL} / \mathrm{kg} / \mathrm{min}$. Individuals with food allergies, who were smokers, habitually consumed protein and/or amino acid supplements, and were on any medication or oral contraceptives (only females) were excluded from the study. Due to the limited study duration, we did not take into account the menstrual cycle of female participants.

\subsection{Supplementation}

The test food contained $6.1 \mathrm{~g} \mathrm{CH}$ (21 kcal; protein, $5.0 \mathrm{~g}$; carbohydrate, $0.3 \mathrm{~g}$ ), whereas the placebo (PL) contained $6.1 \mathrm{~g}$ indigestible dextrin (7 kcal; protein, $0 \mathrm{~g}$; carbohydrate, $5.7 \mathrm{~g}$ ). Caramel coloring agent, sweetener, and coffee flavoring agent were included in both types of food to prevent identification of the foods by taste, flavor, or color. Test food and PL were dissolved in $200 \mathrm{~mL}$ non-caffeine barley tea prior to ingestion. The amino acid composition of $\mathrm{CH}$, which is shown in Table 1, was measured by an amino acid analyzer after hydrolyzation with hydrogen chloride or barium hydroxide as previously reported [21]. The amount of supplementation was decided based on a previous study describing $\mathrm{CH}$ ingestion in humans [22].

Table 1. Amino acid composition of casein hydrolysate.

\begin{tabular}{cccccc}
\hline \multicolumn{6}{c}{ Essential amino acids (mg/g protein) } \\
\hline Lys & 77 & Cys & 3 & Tyr & 37 \\
Thr & 50 & Ile & 52 & Trp & 2 \\
Val & 62 & Leu & 81 & His & 25 \\
Met & 27 & Phe & 35 & & \\
\hline \multicolumn{7}{c}{ Non-essential amino acids } & (mg/g protein) \\
\hline Asp + & 85 & Pro & 108 & Arg & 25 \\
Asn & 63 & Gly & 21 & & \\
Ser & 63 & Ala & 34 & & \\
Glu + & 282 & & &
\end{tabular}

\subsection{Experimental Protocol}

\subsubsection{Preliminary Test}

Experiments were conducted in an open-space laboratory under thermoneutral conditions $\left(\sim 25^{\circ} \mathrm{C}\right.$ and $\sim 50 \%$ relative humidity). Participants reported to the laboratory separated by a minimum of seven days after consumption of the test food or PL. Participants were instructed to refrain from consuming alcohol or caffeine, and from participating in any strenuous physical activity at least 24 hours prior to each experimental trial. Additionally, the night before the experimental session, they consumed a standardized meal (energy content, $750 \mathrm{kcal}$ ) consisting of $\sim 115 \mathrm{~g}$ of carbohydrate, $\sim 20 \mathrm{~g}$ of fats, and $\sim 27 \mathrm{~g}$ of protein. The meal included $500 \mathrm{~mL}$ of non-caffeinated Japanese tea. In addition, participants were asked to consume $500 \mathrm{~mL}$ of water before going to bed the night prior to each experiment. 
Participants reported to the laboratory between 7:00 and 9:00 am in a fasted state except for $500 \mathrm{~mL}$ water at least one hour before their arrival. Upon the arrival of participants, urine samples were collected to measure urine specific gravity (USG) and assess hydration status [23]. Then, the participants' body mass and height were measured using a platform balance (HW-100KC; A \& D, Tokyo, Japan) and a height meter (YS501-P; Sanyu, Tokyo, Japan), respectively. Thereafter, the participants donned a water perfusion suit (Allen-Vanguard, Ottawa, Canada) over shorts and a cotton T-shirt, which covered their whole bodies except for their hands, feet, and head. Skin temperature is known to differ between individuals [24-26] and could influence sweating and cutaneous vascular responses independent of other modulators $[20,27]$. We therefore used the water perfusion suit to clamp skin temperature to minimize inter- and intra-individual variations in this variable. The temperature of the water circulating the suit was maintained as similar to that of skin temperature in normothermic humans at $34{ }^{\circ} \mathrm{C}$ throughout the experiment to mimic a normothermic state [28-31]. The instrumentation was approximately $60 \mathrm{~min}$. After that, baseline (BL) data were collected for $5 \mathrm{~min}$, during which a blood sample was collected from a warmed fingertip. Subsequently, participants ingested the test food or PL dissolved in barley tea as described above and rested for $2 \mathrm{~h}$ in a semi-supine position (Figure 1a). Ingestion of the test food or PL during the first experiment day was randomly assigned, and the washout period was at least seven days.

a. Preliminary experiment

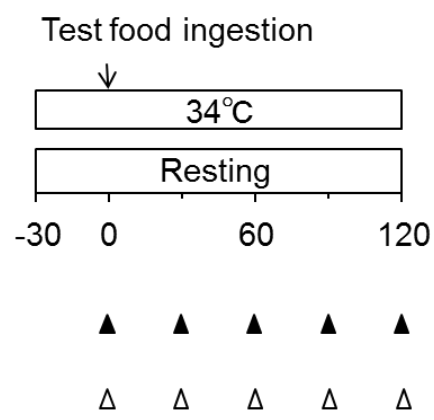

\section{b. Main experiment}

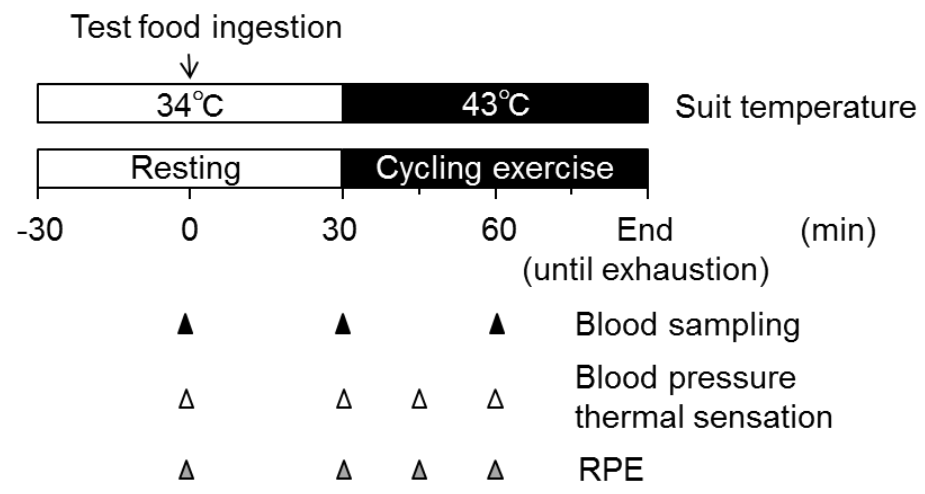

Figure 1. Schematic timeline of the experimental protocols for the preliminary and main experiments. $\mathrm{RPE}$, rating of perceived exhaustion.

\subsubsection{Main Experiment}

General preparations before the food ingestion were the same as the preliminary test, while $\mathrm{VO}_{2} \mathrm{max}$ was assessed at least one week before the main experiment. After consuming the test drink, participants remained in a resting position for $30 \mathrm{~min}$, which was determined from the preliminary test to maximize the plasma amino acid concentrations (see results). During this $30 \mathrm{~min}$, the temperature of the water circulating the suit was maintained at $34^{\circ} \mathrm{C}$. Subsequently, whole body heating was initiated by raising the temperature of the circulating water to $43{ }^{\circ} \mathrm{C}$. At the same time, participants started cycling at $60 \% \mathrm{VO}_{2} \mathrm{max}$ and $60 \mathrm{rpm}$. Cycling was continued until voluntary exhaustion, which was defined as the time point when the participants could no longer maintain the cadence of $50 \mathrm{rpm}$. No fluid consumption was allowed during exercise (Figure 1b).

\subsection{Measurements}

Rectal temperature as an index of Tco was measured continuously by a calibrated thermistor probe (401J; Nikkiso-thermo, Tokyo, Japan) inserted $12 \mathrm{~cm}$ past the anal sphincter. Skin temperature was measured continuously using a type-T thermocouple temperature probe (Inui Engineering, Higashi Osaka, Japan). Weighted mean skin temperature (Tsk) was calculated using four skin temperatures weighting according to the following regional proportions: forearm $30 \%$, chest $30 \%$, 
thigh 20\%, and lower limb 20\% [32]. Mean body temperature was calculated from Tco and Tsk weighting, according to the following proportions: Tco $80 \%$ and Tsk $20 \%$ [33].

Local sweat rate was measured continuously using the ventilated capsule method. A $5.3 \mathrm{~cm}^{2}$ plastic capsule was affixed to the forearm and chest using a topical glue (Collodion; Kanto chemical, Tokyo, Japan). The forearm was placed on a stull at a height level with the heart throughout the experiment. Dry nitrogen gas was passed through each capsule over the skin at a rate of $1.0 \mathrm{~L} / \mathrm{min}$. Water content in the effluent air was measured using a capacitance hygrometer (HMP60; Vaisala, Helsinki, Finland). Local skin blood flow on the forearm was measured continuously using laser Doppler flowmetry (FLO-C1; Omegawave, Inc, Tokyo, Japan) located adjacent to the ventilated capsule. Cutaneous vascular conductance (CVC) was calculated from the ratio of skin blood flow to mean arterial blood pressure. Systolic and diastolic blood pressures were measured every 30 (preliminary experiment) or $15 \mathrm{~min}$ (main experiment) on the arm contralateral to the skin blood flow and sweat rate measurements using the standard auscultatory method. The following equation was used to calculate mean arterial blood pressure: (systolic blood pressure - diastolic blood pressure)/ $3+$ diastolic blood pressure. Heart rate was recorded using a Polar coded WearLink and transmitter and RS800 interface (Polar Electro Oy, Finland). Skin temperatures, Tco, sweat rate, and skin blood flow were recorded by a datalogger at 1-s intervals.

Blood samples were collected from a warmed fingertip prior to supplementation (BL) and every $30 \mathrm{~min}$ afterward in both the preliminary and main experiments. All blood samples were collected in a semi-recumbent position throughout the experiments. Collected blood samples were centrifuged and the extracted plasma samples were immediately frozen at $-30{ }^{\circ} \mathrm{C}$ until the measurement of amino acids. Plasma samples were deproteinized by adding trichloroacetic acid and centrifuged at $15,000 \times \mathrm{g}$ for $15 \mathrm{~min}$ at $4{ }^{\circ} \mathrm{C}$; the supernatant was analyzed using an amino acid analyzer (L-8900; Hitachi High-technologies Corporation, Tokyo, Japan). Thermal sensation and rating of perceived exhaustion (RPE, main experiment only) were recorded prior to the supplementation and every $30 \mathrm{~min}$ (preliminary experiment) or $15 \mathrm{~min}$ (main experiment) afterward.

\subsection{Data and Statistical Analyses}

All continuously recorded variables were averaged over $5 \mathrm{~min}$. Given that mean arterial blood pressure was recorded every $30 \mathrm{~min}$ (preliminary experiment) or $15 \mathrm{~min}$ (main experiment) during each experiment, CVC was also analyzed at the same time points. Changes in the primary outcomes (i.e., Tco, Tsk, and sweat rate) from their BL values $(\Delta)$ were calculated during exercise in the main experiment. In addition, Tco and mean body temperature thresholds and slopes for sweating at each skin site were calculated by using a segmented regression analysis method in the main experiment [34]. This analysis was not conducted for CVC due to the limited number of measurements. To explore the potential relationship between sweat production and changes in plasma amino acid concentration during exercise (main experiment), we plotted $\Delta$ sweat rate against the change in plasma total amino acid ( $\triangle \mathrm{TAA}$ ) concentration $60 \mathrm{~min}$ after the supplementation (and thus $30 \mathrm{~min}$ of exercise). We selected this time point to explore the relationship between $\Delta$ sweat rate and $\triangle \mathrm{TAA}$ during exercise since blood collection was only possible at this time point in most participants.

Two-way repeated measures analysis of variance (ANOVA) was used as the repeated factors of two stage-protocol (BL and every $5 \mathrm{~min}$ after the supplementation till the end of experiment for the preliminary experiment and till $55 \mathrm{~min}$ ( $25 \mathrm{~min}$ of exercise) in the case of the shortest exercise duration observed for the main experiment) and the supplementations (CH and PL) for variables measured in both the preliminary and main experiments. Plasma TAA concentration, mean arterial blood pressure, CVC, thermal sensation, and RPE were analyzed by using two-way repeated measures ANOVA as the repeated factors of the protocol stage (BL and every 15 or 30 min after the supplementations) and test food as well as PL. Huynh-Feldt correction was applied under violation of the assumption of sphericity. Post hoc analyses were performed using a Bonferroni corrected paired $t$-test. Thresholds of Tco and mean body temperature, and slopes for sweating and TTE were compared between the conditions with 
a paired $t$-test. The relationship between $\Delta$ sweat rate and $\Delta$ TAA was evaluated using the Pearson's correlation test. Due to technical difficulties, some variables were only analyzed in a limited number of participants, and indicated in the figure legends and tables. All data are expressed as mean $\pm \mathrm{SD}$. Segmented linear analysis was performed by using GraphPad Prism version 8.3.0 (GraphPad Software, La Jolla, CA). All statistical analyses were performed by using SPSS version 22.0 (IBM, Armonk, NY).

\section{Results}

\subsection{Preliminary Experiment}

A supplementation $x$ time interaction effect was observed for plasma TAA $(P<0.001$, Figure 2$)$. Post hoc analysis revealed that plasma TAA concentration in $\mathrm{CH}$ was significantly higher compared with that in PL at $30 \mathrm{~min}$ after ingestion $(P<0.001)$, although it later returned to a similar level to that in PL (Figure 2). There were no differences in other variables between $\mathrm{CH}$ and PL conditions throughout the experiment (all variables showed $P>0.05$, Table 2). Measurable sweat rate was not observed throughout the preliminary experiment in both $\mathrm{CH}$ and PL trials (data not shown).

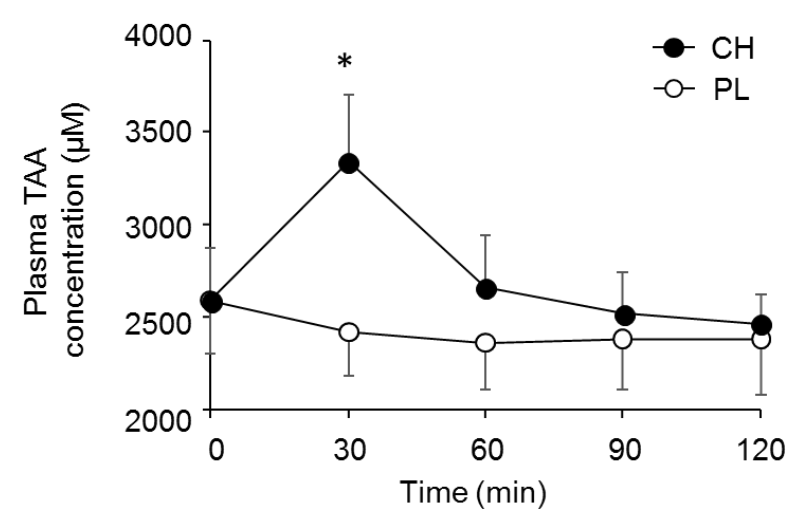

Figure 2. Plot showing the trend of plasma total amino acid (TAA) concentration as a function of time following casein hydrolysate $(\mathrm{CH})$ or placebo $(\mathrm{PL})$ ingestion $(n=9)$ in the preliminary test. Values are expressed as mean \pm SD. ${ }^{*}, P<0.001$. 
Table 2. Physiological and perceptual responses in the preliminary experiment

\begin{tabular}{|c|c|c|c|c|c|c|c|c|}
\hline & & \multirow{2}{*}{$n$} & \multirow{2}{*}{ Baseline } & \multicolumn{4}{|c|}{ Time after the Supplementation } & \multirow{2}{*}{ Interactior } \\
\hline & & & & $30 \mathrm{~min}$ & $60 \mathrm{~min}$ & $90 \mathrm{~min}$ & $120 \mathrm{~min}$ & \\
\hline Heart rate(beats/min) & $\begin{array}{l}\mathrm{CH} \\
\mathrm{PL}\end{array}$ & 10 & $\begin{array}{l}72.2 \pm 8.0 \\
71.2 \pm 7.1\end{array}$ & $\begin{array}{l}72.0 \pm 6.7 \\
71.1 \pm 7.5\end{array}$ & $\begin{array}{l}74.8 \pm 6.6 \\
73.0 \pm 7.9\end{array}$ & $\begin{array}{l}74.5 \pm 7.8 \\
73.3 \pm 8.0\end{array}$ & $\begin{array}{l}76.0 \pm 7.2 \\
74.5 \pm 8.6\end{array}$ & n.s. \\
\hline $\begin{array}{l}\text { Mean arterial blood pressure } \\
(\mathrm{mmHg})\end{array}$ & $\begin{array}{l}\mathrm{CH} \\
\mathrm{PL}\end{array}$ & 10 & $\begin{array}{l}87.1 \pm 6.1 \\
85.1 \pm 6.8\end{array}$ & $\begin{array}{l}85.2 \pm 5.5 \\
85.2 \pm 7.8\end{array}$ & $\begin{array}{l}85.3 \pm 5.0 \\
85.4 \pm 7.2\end{array}$ & $\begin{array}{l}84.7 \pm 6.3 \\
86.7 \pm 5.9\end{array}$ & $\begin{array}{l}85.1 \pm 6.8 \\
85.8 \pm 6.1\end{array}$ & n.s. \\
\hline Body core temperature $\left({ }^{\circ} \mathrm{C}\right)$ & $\begin{array}{l}\mathrm{CH} \\
\mathrm{PL}\end{array}$ & 10 & $\begin{array}{l}36.31 \pm 1.01 \\
36.65 \pm 0.43\end{array}$ & $\begin{array}{l}36.24 \pm 0.87 \\
36.52 \pm 0.37\end{array}$ & $\begin{array}{l}36.40 \pm 0.76 \\
36.58 \pm 0.34\end{array}$ & $\begin{array}{l}36.53 \pm 0.65 \\
36.64 \pm 0.30\end{array}$ & $\begin{array}{l}36.61 \pm 0.56 \\
36.73 \pm 0.28\end{array}$ & n.s. \\
\hline Mean skin temperature $\left({ }^{\circ} \mathrm{C}\right)$ & $\begin{array}{l}\mathrm{CH} \\
\mathrm{PL}\end{array}$ & 8 & $\begin{array}{l}31.66 \pm 0.94 \\
31.62 \pm 0.72\end{array}$ & $\begin{array}{l}31.92 \pm 0.87 \\
31.90 \pm 0.37\end{array}$ & $\begin{array}{l}32.02 \pm 0.91 \\
31.96 \pm 0.42\end{array}$ & $\begin{array}{l}32.13 \pm 0.87 \\
31.91 \pm 0.37\end{array}$ & $\begin{array}{l}32.26 \pm 0.72 \\
31.95 \pm 0.48\end{array}$ & n.s. \\
\hline Mean body temperature $\left({ }^{\circ} \mathrm{C}\right)$ & $\begin{array}{l}\mathrm{CH} \\
\mathrm{PL}\end{array}$ & 8 & $\begin{array}{l}35.29 \pm 0.89 \\
35.62 \pm 0.46\end{array}$ & $\begin{array}{l}35.31 \pm 0.72 \\
35.61 \pm 0.36\end{array}$ & $\begin{array}{l}35.48 \pm 0.64 \\
35.68 \pm 0.34\end{array}$ & $\begin{array}{l}35.61 \pm 0.55 \\
35.73 \pm 0.30\end{array}$ & $\begin{array}{l}35.72 \pm 0.45 \\
35.81 \pm 0.26\end{array}$ & n.s. \\
\hline Skin Blood Flow (AU) & $\begin{array}{l}\mathrm{CH} \\
\mathrm{PL}\end{array}$ & 9 & $\begin{array}{l}0.102 \pm 0.023 \\
0.109 \pm 0.031\end{array}$ & $\begin{array}{l}0.104 \pm 0.026 \\
0.101 \pm 0.021\end{array}$ & $\begin{array}{l}0.101 \pm 0.022 \\
0.100 \pm 0.020\end{array}$ & $\begin{array}{l}0.101 \pm 0.030 \\
0.102 \pm 0.024\end{array}$ & $\begin{array}{l}0.114 \pm 0.032 \\
0.105 \pm 0.026\end{array}$ & n.s. \\
\hline $\mathrm{CVC}(\mathrm{AU} / \mathrm{mmHg})$ & $\begin{array}{l}\mathrm{CH} \\
\mathrm{PL}\end{array}$ & 9 & $\begin{array}{l}0.0012 \pm 0.0003 \\
0.0013 \pm 0.0004\end{array}$ & $\begin{array}{l}0.0012 \pm 0.0003 \\
0.0011 \pm 0.0002\end{array}$ & $\begin{array}{l}0.0012 \pm 0.0003 \\
0.0012 \pm 0.0002\end{array}$ & $\begin{array}{l}0.0012 \pm 0.0003 \\
0.0012 \pm 0.0002 \\
\end{array}$ & $\begin{array}{l}0.0013 \pm 0.0003 \\
0.0013 \pm 0.0003\end{array}$ & n.s. \\
\hline Thermal sensation (AU) & $\begin{array}{l}\mathrm{CH} \\
\mathrm{PL}\end{array}$ & 10 & $\begin{array}{l}3.2 \pm 0.6 \\
3.2 \pm 0.9\end{array}$ & $\begin{array}{l}3.0 \pm 0.8 \\
3.0 \pm 1.1\end{array}$ & $\begin{array}{l}3.0 \pm 0.8 \\
3.2 \pm 0.6\end{array}$ & $\begin{array}{l}3.3 \pm 0.9 \\
3.1 \pm 0.9\end{array}$ & $\begin{array}{l}3.6 \pm 0.5 \\
3.1 \pm 0.7\end{array}$ & n.s. \\
\hline
\end{tabular}

Values are expressed as mean \pm SD. $\mathrm{CH}$, casein hydrolysate; PL, placebo; CVC, cutaneous vascular conductance; n.s., not significant. 


\subsection{Main Experiment}

No difference in TTE during exercise was observed between the conditions (Figure 3). Throughout the experiment, Tco and $\Delta$ Tco were also not different between the conditions (both $P>0.05$, Figure $4 \mathrm{a}$ and Table 3 ). Significant supplementation $\mathrm{x}$ time effect was observed in $\Delta$ Tsk $(P=0.035)$, and post hoc analysis revealed higher $\Delta$ Tsk in $C H$ compared with that in PL at 25 min and from $40 \mathrm{~min}$ to $55 \mathrm{~min}$ after supplementation (Figure $4 \mathrm{~b}$ ). While Tsk showed significant interaction effect between the conditions $(P=0.035)$, post hoc analysis revealed no difference in this parameter at any time point between PL and $\mathrm{CH}$ (Table 3). Significant supplementation $\mathrm{x}$ time effect was observed in the $\Delta$ sweat rate on the chest $(P=0.023)$, which indicated a higher $\Delta$ sweat rate in $C H$ compared with PL at 45 and 50 min after supplementation $(P<0.05$ for both time points, Figure $4 \mathrm{c})$. On the other hand, $\Delta$ sweat rate on the forearm was not significantly different between the conditions $(P=0.805$ for interaction, Figure $4 \mathrm{~d}$ ). No differences in body mass loss were observed between supplementations during the experiment $(0.62 \pm 0.15$ and $0.77 \pm 0.40 \%$ for $\mathrm{CH}$ and $\mathrm{PL}$, respectively). The end exercise Tco, heart rate, and Tsk were $37.54 \pm 0.31$ and $37.55 \pm 0.48^{\circ} \mathrm{C}, 155.8 \pm 12.0$, and $161.8 \pm 6.9$ beats $/ \mathrm{min}$, and $34.96 \pm 0.59$ and $34.79 \pm 0.76^{\circ} \mathrm{C}$ for $\mathrm{CH}$ and $\mathrm{PL}$, respectively (all $P>0.05$ ).

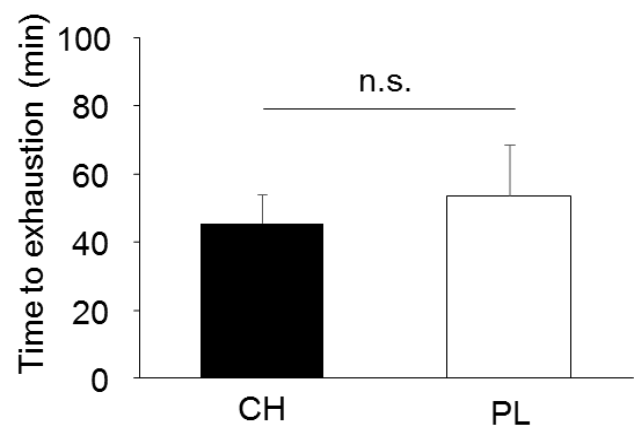

Figure 3. Time to exhaustion in casein hydrolysate $(\mathrm{CH})$ and placebo $(\mathrm{PL})$ conditions during exercise in the main experiment $(n=10)$. Values are expressed as mean \pm SD.
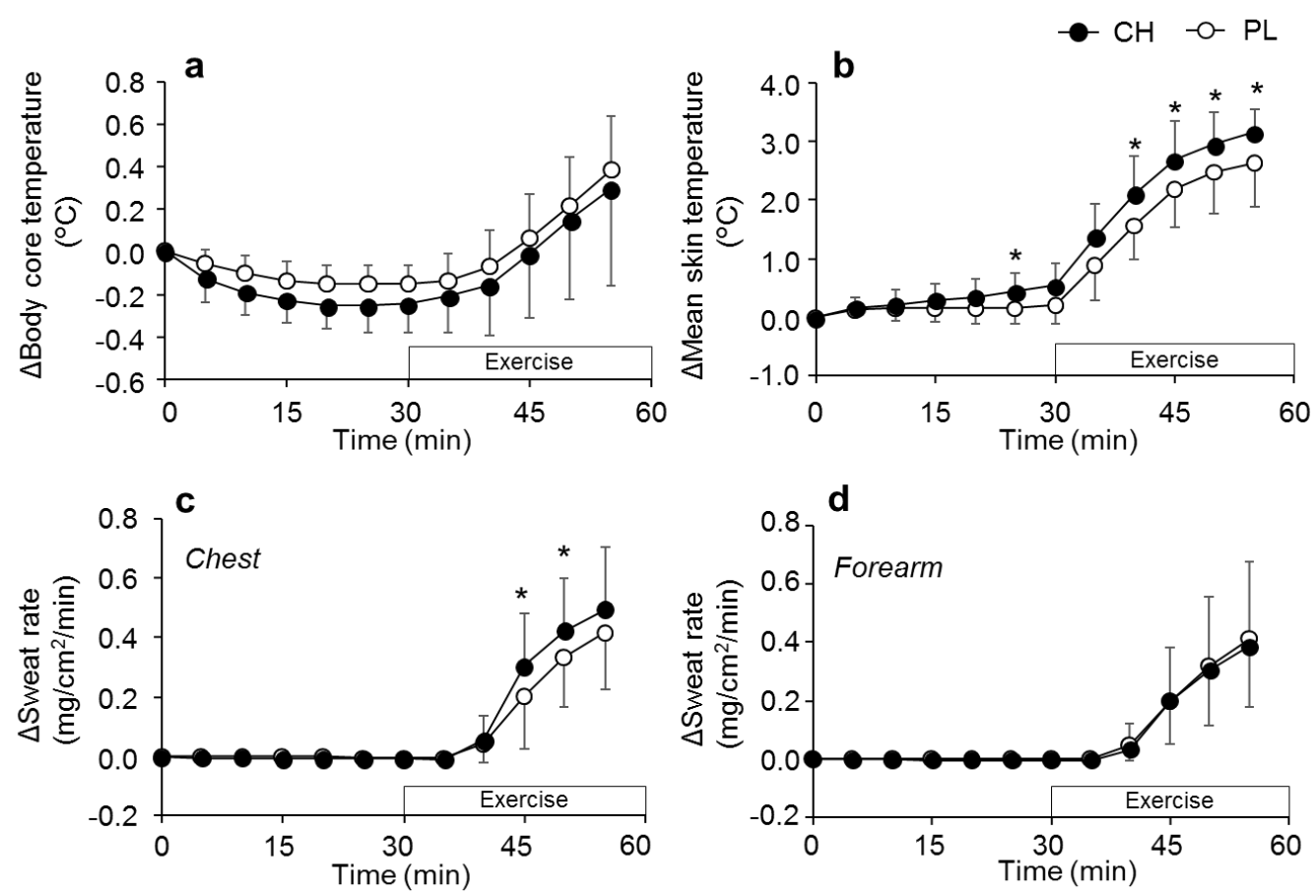

Figure 4. Changes in (a) body core temperature $(n=9),(\mathbf{b})$ mean skin temperature $(n=8)$, (c) chest sweat rate $(n=9)$, and (d) forearm sweat rate $(n=10)$ following casein hydrolysate $(\mathrm{CH})$ or placebo $(\mathrm{PL})$ ingestions in the main experiment. Values are expressed as mean $\pm \mathrm{SD} .{ }^{*}, P<0.05$. 
Table 3. Physiological and perceptual responses in the main experiment.

\begin{tabular}{|c|c|c|c|c|c|c|c|c|}
\hline & & \multirow{2}{*}{$n$} & \multirow{2}{*}{ Baseline } & \multicolumn{4}{|c|}{ Time after the Supplementation (Duration of Exercise) } & \multirow{2}{*}{ Interaction } \\
\hline & & & & $\begin{array}{c}15 \min (-15 \\
\min )\end{array}$ & $30 \mathrm{~min}(0 \mathrm{~min})$ & $45 \min (15 \mathrm{~min})$ & $55 \min (25 \mathrm{~min})$ & \\
\hline Heart rate (beats/min) & $\begin{array}{l}\mathrm{CH} \\
\mathrm{PL}\end{array}$ & 10 & $\begin{array}{l}70.9 \pm 9.3 \\
69.3 \pm 6.5\end{array}$ & $\begin{array}{l}69.0 \pm 8.7 \\
66.6 \pm 5.3\end{array}$ & $\begin{array}{c}70.7 \pm 10.0 \\
69.2 \pm 6.7\end{array}$ & $\begin{array}{l}139.3 \pm 7.6 \\
138.1 \pm 8.3\end{array}$ & $\begin{array}{l}147.7 \pm 10.4 \\
149.0 \pm 11.5\end{array}$ & n.s. \\
\hline $\begin{array}{l}\text { Mean arterial blood } \\
\text { pressure }(\mathrm{mmHg})\end{array}$ & $\begin{array}{l}\mathrm{CH} \\
\mathrm{PL}\end{array}$ & 7 & $\begin{array}{l}79.6 \pm 4.2 \\
78.3 \pm 5.0 \\
\end{array}$ & $\begin{array}{l}78.0 \pm 6.8 \\
76.1 \pm 4.6 \\
\end{array}$ & $\begin{array}{l}76.3 \pm 6.8 \\
76.5 \pm 7.7 \\
\end{array}$ & $\begin{array}{l}86.5 \pm 5.9 \\
85.3 \pm 7.2 \\
\end{array}$ & - & n.s. \\
\hline $\begin{array}{l}\text { Body core temperature } \\
\left({ }^{\circ} \mathrm{C}\right)\end{array}$ & $\begin{array}{l}\mathrm{CH} \\
\mathrm{PL}\end{array}$ & 9 & $\begin{array}{l}36.73 \pm 0.76 \\
36.48 \pm 0.76\end{array}$ & $\begin{array}{l}36.50 \pm 0.77 \\
36.34 \pm 0.73\end{array}$ & $\begin{array}{l}36.48 \pm 0.68 \\
36.33 \pm 0.71 \\
\end{array}$ & $\begin{array}{l}36.72 \pm 0.53 \\
36.55 \pm 0.61 \\
\end{array}$ & $\begin{array}{l}37.03 \pm 0.40 \\
36.87 \pm 0.60\end{array}$ & n.s. \\
\hline $\begin{array}{l}\text { Mean skin temperature } \\
\left({ }^{\circ} \mathrm{C}\right)\end{array}$ & $\begin{array}{l}\mathrm{CH} \\
\mathrm{PL}\end{array}$ & 8 & $\begin{array}{l}31.52 \pm 0.71 \\
31.82 \pm 0.98 \\
\end{array}$ & $\begin{array}{l}31.81 \pm 0.88 \\
31.98 \pm 0.84\end{array}$ & $\begin{array}{l}32.06 \pm 0.65 \\
32.03 \pm 0.82\end{array}$ & $\begin{array}{l}34.20 \pm 0.91 \\
34.00 \pm 0.80\end{array}$ & $\begin{array}{l}34.67 \pm 0.84 \\
34.45 \pm 0.58\end{array}$ & $P=0.035$ \\
\hline $\begin{array}{c}\text { Mean body temperature } \\
\left({ }^{\circ} \mathrm{C}\right)\end{array}$ & $\begin{array}{l}\mathrm{CH} \\
\mathrm{PL}\end{array}$ & 7 & $\begin{array}{l}35.58 \pm 0.58 \\
35.50 \pm 0.75\end{array}$ & $\begin{array}{l}35.45 \pm 0.56 \\
35.45 \pm 0.72 \\
\end{array}$ & $\begin{array}{l}35.49 \pm 0.50 \\
35.45 \pm 0.69 \\
\end{array}$ & $\begin{array}{l}36.15 \pm 0.45 \\
36.02 \pm 0.56\end{array}$ & $\begin{array}{l}36.52 \pm 0.35 \\
36.37 \pm 0.51 \\
\end{array}$ & n.s. \\
\hline Skin blood flow (AU) & $\begin{array}{l}\mathrm{CH} \\
\mathrm{PL}\end{array}$ & 10 & $\begin{array}{l}0.084 \pm 0.028 \\
0.109 \pm 0.046\end{array}$ & $\begin{array}{l}0.079 \pm 0.015 \\
0.094 \pm 0.032\end{array}$ & $\begin{array}{l}0.082 \pm 0.021 \\
0.107 \pm 0.034 \\
\end{array}$ & $\begin{array}{l}0.482 \pm 0.326 \\
0.491 \pm 0.197\end{array}$ & $\begin{array}{l}0.699 \pm 0.421 \\
0.764 \pm 0.338 \\
\end{array}$ & n.s. \\
\hline $\mathrm{CVC}(\mathrm{AU} / \mathrm{mmHg})$ & $\begin{array}{l}\mathrm{CH} \\
\mathrm{PL}\end{array}$ & 7 & $\begin{array}{l}0.0011 \pm 0.0004 \\
0.0011 \pm 0.0003\end{array}$ & $\begin{array}{l}0.0010 \pm 0.0001 \\
0.0011 \pm 0.0003\end{array}$ & $\begin{array}{l}0.0010 \pm 0.0003 \\
0.0012 \pm 0.0002\end{array}$ & $\begin{array}{l}0.0039 \pm 0.0016 \\
0.0039 \pm 0.0013\end{array}$ & - & n.s. \\
\hline Plasma TAA $(\mu \mathrm{M})$ & $\begin{array}{l}\mathrm{CH} \\
\mathrm{PL}\end{array}$ & 10 & $\begin{array}{l}2604 \pm 257 \\
2686 \pm 242 \\
\end{array}$ & - & $\begin{array}{c}3507 \pm 344^{*} \\
2649 \pm 292\end{array}$ & - & - & $P<0.001$ \\
\hline Thermal sensation (AU) & $\begin{array}{l}\mathrm{CH} \\
\mathrm{PL}\end{array}$ & 10 & $\begin{array}{l}3.2 \pm 1.0 \\
3.4 \pm 0.7\end{array}$ & - & $\begin{array}{l}3.3 \pm 1.4 \\
3.6 \pm 1.3\end{array}$ & $\begin{array}{l}6.6 \pm 0.7 \\
6.5 \pm 0.5\end{array}$ & - & n.s. \\
\hline RPE (AU) & $\begin{array}{l}\mathrm{CH} \\
\mathrm{PL}\end{array}$ & 10 & $\begin{array}{l}8.6 \pm 2.2 \\
8.5 \pm 2.2\end{array}$ & - & $\begin{array}{l}9.4 \pm 2.8 \\
9.8 \pm 2.8\end{array}$ & $\begin{array}{l}15.0 \pm 2.3 \\
14.2 \pm 1.5\end{array}$ & - & n.s. \\
\hline
\end{tabular}

Values are expressed as mean \pm SD. CH, casein hydrolysate; PL, placebo; CVC, cutaneous vascular conductance; TAA, total amino acids; RPE, rating of perceived exhaustion; n.s., not significant. 
The elevated $\Delta$ sweat rate on the chest in $\mathrm{CH}$ relative to that in PL was associated with higher slopes for sweating to increasing Tco $(P=0.019)$ and mean body temperature $(P=0.090$, Table 4$)$. For both chest and forearm sweat rate, Tco thresholds in $\mathrm{CH}$ were significantly higher than that in PL $(P=0.005$ and $P=0.006$, respectively), while this difference was not observed in both $\Delta$ Tco and $\Delta$ mean body temperature thresholds. Plasma TAA was higher in $\mathrm{CH}$ than that in PL at $30 \mathrm{~min}$ after supplementation (Table 3).

Table 4. Body core temperature and mean body temperature thresholds and slopes for sweating in the main experiment.

\begin{tabular}{ccccccc}
\hline & \multicolumn{9}{c}{ Threshold $\left({ }^{\circ} \mathbf{C}\right)$} & \multicolumn{2}{c}{ Slope $\left(\mathbf{m g} / \mathrm{cm}^{2} / \mathbf{m i n}^{\circ} \mathbf{C}\right)$} \\
\cline { 2 - 7 } & Tco & $\Delta$ Tco & Tb & $\Delta$ Tb & Tco & Tb \\
\hline Chest sweat rate \\
CH & $35.94 \pm 0.44^{*}$ & $0.31 \pm 0.22$ & $35.47 \pm 0.44$ & $0.69 \pm 0.24$ & $0.97 \pm 0.38^{*}$ & $0.79 \pm 0.40$ \\
PL & $35.72 \pm 0.46$ & $0.23 \pm 0.22$ & $35.26 \pm 0.40$ & $0.56 \pm 0.29$ & $0.71 \pm 0.25$ & $0.61 \pm 0.29$ \\
\hline \multicolumn{7}{c}{ Forearm sweat rate } \\
CH & $35.99 \pm 0.45^{*}$ & $0.36 \pm 0.21$ & $35.53 \pm 0.45$ & $0.75 \pm 0.26$ & $0.79 \pm 0.61$ & $0.60 \pm 0.37$ \\
PL & $35.77 \pm 0.40$ & $0.29 \pm 0.28$ & $35.30 \pm 0.31$ & $0.60 \pm 0.40$ & $0.62 \pm 0.32$ & $0.59 \pm 0.31$ \\
\hline
\end{tabular}

Values are expressed as mean $\pm \mathrm{SD}$. $\mathrm{CH}$, casein hydrolysate; PL, placebo; Tco, body core temperature; $\mathrm{Tb}$, mean body temperature; ${ }^{*} P<0.05$.

At $60 \mathrm{~min}$ after supplementation, the $\Delta$ sweat rate on the chest was positively correlated with $\triangle$ TAA $(r=0.722, P<0.001$, Figure 5a), while no significant correlation was observed between $\Delta$ sweat rate on the forearm and $\triangle \mathrm{TAA}(r=0.444, P=0.057$, Figure $5 \mathrm{~b})$. The positive correlation between $\Delta$ sweat rate on the chest and $\triangle$ TAA was particularly significant in the PL group $(r=0.817, P=0.013$, $n=8$ in PL, $r=0.636, P=0.066, n=9$ in $\mathrm{CH}$ ). There were no differences in other variables between $\mathrm{CH}$ and PL throughout the experiment (Table 3).
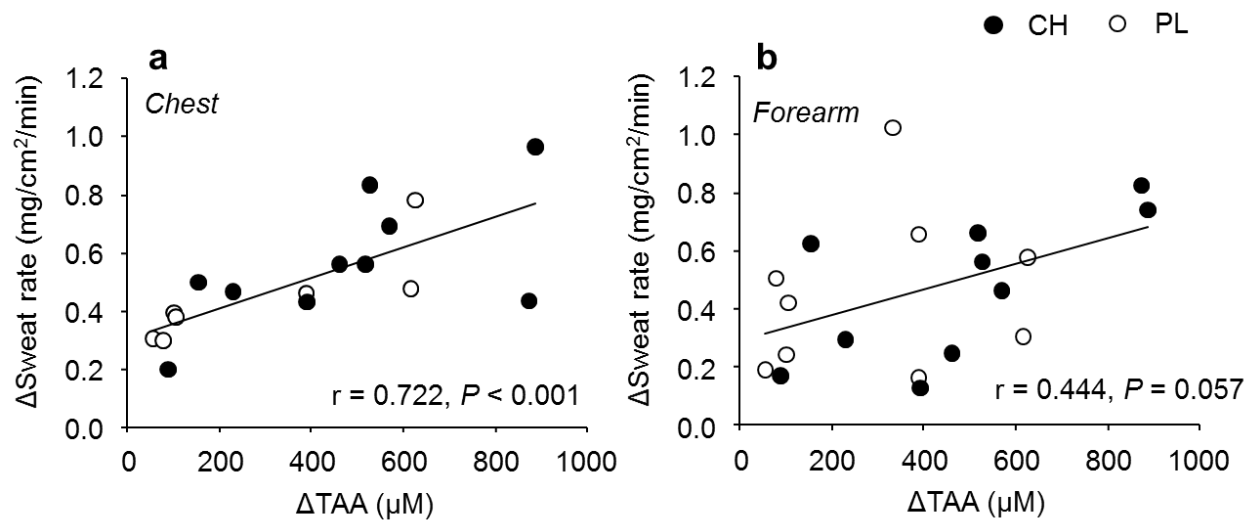

Figure 5. Relationship between changes in sweat rate ( $\Delta$ sweat rate) and plasma total amino acid $(\triangle T A A)$ concentration at 60 min after casein hydrolysate $(\mathrm{CH})$ or placebo $(\mathrm{PL})$ ingestion in the main experiment. Relationships (a) between $\Delta$ sweat rate on the chest and $\triangle \mathrm{TAA}(n=18)$, and $(\mathbf{b})$ between $\Delta$ sweat rate on the forearm and $\triangle \mathrm{TAA}(n=19)$.

\section{Discussion}

Contrary to our hypothesis, we found that $\mathrm{CH}$ ingestion did not influence Tc elevation during exercise in the heat. We observed higher Tco thresholds for sweating in CH compared with that in PL. However, this response might be due to a slightly higher Tco before $\mathrm{CH}$ ingestion when compared with PL supplementation and not due to $\mathrm{CH}$ ingestion itself (see discussion below), which contradicts our hypothesis. Interestingly, $\mathrm{CH}$ ingestion increased Tsk and chest sweat rate without affecting responses on the forearm. Higher chest sweat rate in $\mathrm{CH}$ compared with that in PL was associated with greater 
sudomotor sensitivity to increasing Tco and possibly higher plasma amino acid concentration. We did not observe any influence of $\mathrm{CH}$ ingestion on TTE. These results suggest that $\mathrm{CH}$ ingestion prior to exercise elevates thermoregulatory sweating and skin temperature without affecting Tco during exercise in the heat.

Several studies have reported that amino acid ingestion does not affect Tco during exercise [16-18]. Contrary to this general observation, we originally hypothesized that $\mathrm{CH}$ ingestion, which increases blood amino acid concentration [35], would elevate Tco during exercise since it has been shown to increase postprandial energy expenditure to a greater extent than the equivalent amount of amino acid consumption [14]. This response, if any, might occur through diet-induced thermogenesis via mitochondrial BCAA catabolism in brown adipose tissue [11,36,37]. Despite these assumptions, we observed similar Tco between $\mathrm{CH}$ and PL ingestions, suggesting that $\mathrm{CH}$ does not affect Tco during exercise in the heat. Unexpectedly, Tco during exercise was low in both conditions. Given that the change in Tco from pre-exercise level (changes from the time point at 30 min in Figure 4a) during exercise was comparable to previous studies [16], the observed low Tco was probably due to a low resting Tco prior to the commencement of exercise. The low resting Tco at baseline was related to a female participant who showed quite a low rectal temperature, which was 34.75 and $34.66{ }^{\circ} \mathrm{C}$ for the $\mathrm{CH}$ and PL conditions, respectively. As we did not assess the menstrual phase in female participants in the present study, it is unclear how the menstrual phase potentially influenced the low Tco response in this participant. Thus, the precise reason(s) for the low Tco in this female participant remain unknown. Nevertheless, as we did not observe an increase in Tco after $\mathrm{CH}$ ingestion, it is assumed that the amount of $\mathrm{CH}$ consumed might be too small to affect these responses in the present study. Further studies are required to explore the impact of ingestion of a high dose of $\mathrm{CH}$ on human thermoregulatory responses during exercise.

We observed an elevated Tco threshold for initiating sweating upon $\mathrm{CH}$ ingestion. However, we consider that the observed higher Tco threshold for sweating in $\mathrm{CH}$ than in PL was independent of the supplementation effect because $\Delta$ Tco thresholds for sweating were not different between supplementations. The resting Tco before supplementation was already slightly higher in the $\mathrm{CH}$ condition compared with the PL condition (Table 3), in which the response likely contributed to an elevated Tco threshold for initiating sweating during exercise, apart from the supplementation effects. Once the sweating was initiated, we observed higher chest sweat rate in the $\mathrm{CH}$ condition compared with the PL condition, without modulating forearm sweat rate during exercise in the heat, demonstrating heterogeneous effects of $\mathrm{CH}$ on sweating across skin sites. Supporting this observation, $\mathrm{CH}$ ingestion did not affect whole body sweating. The elevated slope for chest sweating to increasing Tco implies peripheral modification of sweating following $\mathrm{CH}$ ingestion $[20,38,39]$. Given that a similar trend was observed even with the slope calculated as a response to mean body temperature and that the local chest skin temperature was not different between supplementations (data not shown), the increased chest sweat rate following $\mathrm{CH}$ ingestion might be independent of skin temperature. Interestingly, we observed a positive correlation between chest sweat rate and plasma TAA concentration and a slightly weak correlation between forearm sweat rate and plasma TAA concentration at $30 \mathrm{~min}$ of exercise. However, the precise interpretation of this result was somewhat difficult since several studies have demonstrated that ingestion of amino acids does not affect sweat production (whole body sweating) during exercise [16,17]. In addition, it has been shown that intravenous infusion of amino acids did not alter peripheral sweat production during passive heat stress in humans [19]. Furthermore, given that we observed a co-relationship between sweat rate and TAA even in the PL condition, there is a possibility that the changes in TAA could potentially influence sweating during exercise independent of the supplementation effect per se. Thus, the relationship between amino acids and sweating is inconsistent between previous and present studies. Further studies are required to bridge the gap of knowledge between the present study and those previous studies to elucidate the impact of increased plasma amino acid concentration on sweating during exercise. 
$\mathrm{CH}$ ingestion increased mean skin temperature compared with that of PL, however the magnitude of the elevation might be too small to affect physiological responses. We are unaware of the precise reason(s) for an increased Tsk following $\mathrm{CH}$ ingestion, but one can speculate that $\mathrm{CH}$ would elevate Tsk due to its potential heterogeneous vasodilation effect across several body sites [40,41]. However, as we measured skin blood flow only on the forearm, the trend of skin blood flow across several body sites and the precise influence of $\mathrm{CH}$ ingestion on skin perfusion remains unknown.

Previous studies have shown that high skin temperature $\left(\sim 35^{\circ} \mathrm{C}\right)$ and dehydration $(4 \%)$ attenuate endurance exercise performance in the heat [3-6]. We observed a high skin temperature where the level attenuates exercise performance [5] while the magnitude of the differences between conditions $\left(\sim+0.3^{\circ} \mathrm{C}\right)$ might not be large enough to affect the performance. Furthermore, non-uniform increases in sweating after $\mathrm{CH}$ ingestion implies a relatively small impact of this supplementation on whole body sweat loss and thus dehydration. We also found a high thermal sensation during exercise in both conditions, suggesting that perceptional thermal sensation might also affect exercise performance in both supplementation conditions in this study, which is in line with previously reported studies [42-44]. Therefore, irrespective of the differences in supplementation, we considered that the high skin temperature and thermal sensation, but not dehydration, affected exercise tolerance in the heat in this study.

There were several limitations in our study. First, we used the minimum sample size for an intervention study and thus additional experiments are required to validate our findings. Second, we did not measure resting metabolic rate after $\mathrm{CH}$ ingestion, which is a fundamental measurement in this type of research. Thus, future studies are required to accurately interpret the results of this study. Third, we did not control for the menstrual cycle in female participants, which might potentially affect physiological responses in this population. Fourth, we observed a slight attenuation of Tco during the resting period prior to exercise despite wearing a water perfusion suit to mimic a normothermic state. We observed a lower skin temperature $\left(\sim 31.6^{\circ} \mathrm{C}\right)$ than those of comparable previous studies $\left(\sim 34^{\circ} \mathrm{C}\right)$, which used a similar water perfusion suit $[28,45]$. We were unaware why this occurred in the present study but the low skin temperature might contribute to the attenuation in resting Tco prior to the exercise. It remained unknown if and how the slightly lowered Tco prior to the exercise affected our general findings in the present study. Finally, the usage of a water perfusion suit may limit our ability to assess the impact of $\mathrm{CH}$ during exercise in real-world situations such as a condition under a high ambient temperature permitting the evaporation of sweat.

\section{Conclusions}

In conclusion, this study revealed that $\mathrm{CH}$ ingestion prior to exercise elevated sweating by modulating peripheral sudomotor sensitivity and skin temperature without affecting Tco and exercise tolerance during exercise in the heat. The physiological link between observed amino acid concentration and sweat production during exercise needs to be explored further.

Author Contributions: T.A., Y.S., Y.M., H.N., T.S., and Y.T. conceived and designed the study. Data were collected by T.A., C.Y., Y.F., and Y.S. Data were analyzed by T.A., C.Y., Y.F., and Y.S. The manuscript was written by T.A. and Y.S. All authors contributed to data interpretation as well as editing and critical revision of the manuscript. All authors have read and agreed to the published version of the manuscript.

Funding: This study was supported by the Morinaga Milk Industry Co. Ltd.

Acknowledgments: We thank our volunteers for participating in this study. We appreciate Tomoyuki Yokoyama for his medical support. This study was a graduate research project of CY and YF for their bachelor degree. We would like to thank Editage (www.editage.com) for the English language editing.

Conflicts of Interest: Y.S., Y.M., H.N., T.S., and Y.T. are employees of the Morinaga Milk Industry Co. Ltd. Test foods were supplied by the Morinaga Milk Industry Co., Ltd. The views expressed in this manuscript are those of the authors and do not represent views of the Morinaga Milk Industry Co. Ltd. 


\section{References}

1. Nybo, L.; Rasmussen, P.; Sawka, M.N. Performance in the heat-physiological factors of importance for hyperthermia-induced fatigue. Compr. Physiol. 2014, 4, 657-689. [CrossRef] [PubMed]

2. Sawka, M.N.; Leon, L.R.; Montain, S.J.; Sonna, L.A. Integrated physiological mechanisms of exercise performance, adaptation, and maladaptation to heat stress. Compr. Physiol. 2011, 1, 1883-1928. [CrossRef]

3. Gonzalez-Alonso, J.; Teller, C.; Andersen, S.L.; Jensen, F.B.; Hyldig, T.; Nielsen, B. Influence of body temperature on the development of fatigue during prolonged exercise in the heat. J. Appl. Physiol. 1999, 86, 1032-1039. [CrossRef]

4. Nielsen, B.; Hales, J.R.; Strange, S.; Christensen, N.J.; Warberg, J.; Saltin, B. Human circulatory and thermoregulatory adaptations with heat acclimation and exercise in a hot, dry environment. J. Physiol. 1993, 460, 467-485. [CrossRef] [PubMed]

5. Ely, B.R.; Cheuvront, S.N.; Kenefick, R.W.; Sawka, M.N. Aerobic performance is degraded, despite modest hyperthermia, in hot environments. Med. Sci. Sports Exerc. 2010, 42, 135-141. [CrossRef] [PubMed]

6. Sawka, M.N.; Cheuvront, S.N.; Kenefick, R.W. High skin temperature and hypohydration impair aerobic performance. Exp. Physiol. 2012, 97, 327-332. [CrossRef] [PubMed]

7. Bergman, B.C.; Brooks, G.A. Respiratory gas-exchange ratios during graded exercise in fed and fasted trained and untrained men. J. Appl. Physiol. 1999, 86, 479-487. [CrossRef]

8. Hayashi, K.; Ito, N.; Ichikawa, Y.; Suzuki, Y. Effect of food intake on the ventilatory response to increasing core temperature during exercise. Appl. Physiol. Nutr. Metab. 2019, 44, 22-30. [CrossRef]

9. Hayashi, K.; Ito, N.; Ichikawa, Y.; Suzuki, Y. Effect of postprandial thermogenesis on the cutaneous vasodilatory response during exercise. Appl. Physiol. Nutr. Metab. 2014, 39, 920-926. [CrossRef]

10. Flatt, J.P. The biochemistry of energy expenditure. In Recent Advances in Obesity Research; GA, B., Ed.; Newman Publishing: London, UK, 1978; pp. 211-228.

11. Yoneshiro, T.; Wang, Q.; Tajima, K.; Matsushita, M.; Maki, H.; Igarashi, K.; Dai, Z.; White, P.J.; McGarrah, R.W.; Ilkayeva, O.R.; et al. BCAA catabolism in brown fat controls energy homeostasis through SLC25A44. Nature 2019, 572, 614-619. [CrossRef]

12. Acheson, K.J.; Blondel-Lubrano, A.; Oguey-Araymon, S.; Beaumont, M.; Emady-Azar, S.; Ammon-Zufferey, C.; Monnard, I.; Pinaud, S.; Nielsen-Moennoz, C.; Bovetto, L. Protein choices targeting thermogenesis and metabolism. Am. J. Clin. Nutr. 2011, 93, 525-534. [CrossRef] [PubMed]

13. Craft, I.L.; Geddes, D.; Hyde, C.W.; Wise, I.J.; Matthews, D.M. Absorption and malabsorption of glycine and glycine peptides in man. Gut 1968, 9, 425-437. [CrossRef] [PubMed]

14. Matsunaga, Y.; Sakata, Y.; Yago, T.; Nakamura, H.; Shimizu, T.; Takeda, Y. Effects of Glucose with Casein Peptide Supplementation on Post-Exercise Muscle Glycogen Resynthesis in C57BL/6J Mice. Nutrients 2018, 10, 753. [CrossRef] [PubMed]

15. Matsunaga, Y.; Tamura, Y.; Takahashi, Y.; Masuda, H.; Hoshino, D.; Kitaoka, Y.; Saito, N.; Nakamura, H.; Takeda, Y.; Hatta, H. Pre-exercise casein peptide supplementation enhances endurance training-induced mitochondrial enzyme activity in slow twitch muscle, but not fast twitch muscle of high fat diet-fed mice. J. Phys. Fit. Sports Med. 2015, 4, 377-384. [CrossRef]

16. Cheuvront, S.N.; Carter, R., III; Kolka, M.A.; Lieberman, H.R.; Kellogg, M.D.; Sawka, M.N. Branched-chain amino acid supplementation and human performance when hypohydrated in the heat. J. Appl. Physiol. 2004, 97, 1275-1282. [CrossRef]

17. Tumilty, L.; Davison, G.; Beckmann, M.; Thatcher, R. Failure of oral tyrosine supplementation to improve exercise performance in the heat. Med. Sci. Sports Exerc. 2014, 46, 1417-1425. [CrossRef]

18. Tyler, C.J.; Coffey, T.R.; Hodges, G.J. Acute L-arginine supplementation has no effect on cardiovascular or thermoregulatory responses to rest, exercise, and recovery in the heat. Eur. J. Appl. Physiol. 2016, 116, 363-371. [CrossRef]

19. Nakajima, Y.; Takamata, A.; Matsukawa, T.; Sessler, D.I.; Kitamura, Y.; Ueno, H.; Tanaka, Y.; Mizobe, T. Effect of amino acid infusion on central thermoregulatory control in humans. Anesthesiology 2004, 100, 634-639. [CrossRef]

20. Nadel, E.R.; Mitchell, J.W.; Saltin, B.; Stolwijk, J.A. Peripheral modifications to the central drive for sweating. J. Appl. Physiol. 1971, 31, 828-833. [CrossRef]

21. Takatsu, Z.; Tsuda, M.; Yamada, A.; Matsumoto, H.; Takai, A.; Takeda, Y.; Takase, M. Elephant's breast milk contains large amounts of glucosamine. J. Vet. Med. Sci. 2016, 79, 524-533. [CrossRef] 
22. Hirose, N.; Sato, M.; Yanagisawa, O.; Fukubayashi, T. Milk Peptide Intake May Decrease Muscle Damage after Eccentric Exercise. Int. J. Sport Health Sci. 2013, 11, 20-28. [CrossRef]

23. Sawka, M.N.; Burke, L.M.; Eichner, E.R.; Maughan, R.J.; Montain, S.J.; Stachenfeld, N.S. American College of Sports Medicine position stand. Exercise and fluid replacement. Med. Sci. Sports Exerc. 2007, 39, 377-390. [CrossRef] [PubMed]

24. Kuwahara, T.; Inoue, Y.; Taniguchi, M.; Ogura, Y.; Ueda, H.; Kondo, N. Effects of physical training on heat loss responses of young women to passive heating in relation to menstrual cycle. Eur. J. Appl. Physiol. 2005, 94, 376-385. [CrossRef] [PubMed]

25. Lamarche, D.T.; Notley, S.R.; Poirier, M.P.; Kenny, G.P. Fitness-related differences in the rate of whole-body total heat loss in exercising young healthy women are heat-load dependent. Exp. Physiol. 2018, 103, 312-317. [CrossRef] [PubMed]

26. Yanagimoto, S.; Aoki, K.; Horikawa, N.; Shibasaki, M.; Inoue, Y.; Nishiyasu, T.; Kondo, N. Sweating response in physically trained men to sustained handgrip exercise in mildly hyperthermic conditions. Acta. Physiol. Scand. 2002, 174, 31-39. [CrossRef] [PubMed]

27. Wingo, J.E.; Low, D.A.; Keller, D.M.; Brothers, R.M.; Shibasaki, M.; Crandall, C.G. Skin blood flow and local temperature independently modify sweat rate during passive heat stress in humans. J. Appl. Physiol. 2010, 109, 1301-1306. [CrossRef] [PubMed]

28. Amano, T.; Fujii, N.; Inoue, Y.; Kondo, N. Cutaneous adrenergic nerve blockade attenuates sweating during incremental exercise in habitually trained men. J. Appl. Physiol. 2018, 125, 1041-1050. [CrossRef]

29. Amano, T.; Ichinose, M.; Inoue, Y.; Nishiyasu, T.; Koga, S.; Kenny, G.P.; Kondo, N. Influence of forearm muscle metaboreceptor activation on sweating and cutaneous vascular responses during dynamic exercise. Am. J. Physiol. Regul. Integr. Comp. Physiol. 2016, 310, R1332-R1339. [CrossRef]

30. Fanger, P.O. Assessment of man's thermal comfort in practice. Br. J. Ind. Med. 1973, 30, 313-324. [CrossRef]

31. Low, D.A.; Vu, A.; Brown, M.; Davis, S.L.; Keller, D.M.; Levine, B.D.; Crandall, C.G. Temporal Thermometry Fails to Track Body Core Temperature during Heat Stress. Med. Sci. Sports Exerc. 2007, 39, 1029-1035. [CrossRef]

32. Ramanathan, N.L. A new weighting system for mean surface temperature of the hunan body. J. Appl. Physiol. 1964, 19, 531-533. [CrossRef] [PubMed]

33. Stolwijk, J.A.; Hardy, J.D. Partitional calorimetric studies of responses of man to thermal transients. J. Appl. Physiol. 1966, 21, 967-977. [CrossRef] [PubMed]

34. Cheuvront, S.N.; Bearden, S.E.; Kenefick, R.W.; Ely, B.R.; Degroot, D.W.; Sawka, M.N.; Montain, S.J. A simple and valid method to determine thermoregulatory sweating threshold and sensitivity. J. Appl. Physiol. 2009, 107, 69-75. [CrossRef] [PubMed]

35. Calbet, J.A.; Holst, J.J. Gastric emptying, gastric secretion and enterogastrone response after administration of milk proteins or their peptide hydrolysates in humans. Eur. J. Nutr. 2004, 43, 127-139. [CrossRef] [PubMed]

36. Hibi, M.; Oishi, S.; Matsushita, M.; Yoneshiro, T.; Yamaguchi, T.; Usui, C.; Yasunaga, K.; Katsuragi, Y.; Kubota, K.; Tanaka, S.; et al. Brown adipose tissue is involved in diet-induced thermogenesis and whole-body fat utilization in healthy humans. Int. J. Obes. 2016, 40, 1655-1661. [CrossRef] [PubMed]

37. Newsholme, E.A.; Leech, T.R. Functional Biochemistry in Health and Disease; Wiley-Blackwell: Oxford, UK, 2010; pp. 203-206.

38. Shibasaki, M.; Wilson, T.E.; Crandall, C.G. Neural control and mechanisms of eccrine sweating during heat stress and exercise. J. Appl. Physiol. 2006, 100, 1692-1701. [CrossRef]

39. Van Beaumont, W.; Bullard, R.W. Sweating: Direct influence of skin temperature. Science 1965, 147, $1465-1467$. [CrossRef]

40. Hirota, T.; Nonaka, A.; Matsushita, A.; Uchida, N.; Ohki, K.; Asakura, M.; Kitakaze, M. Milk casein-derived tripeptides, VPP and IPP induced NO production in cultured endothelial cells and endothelium-dependent relaxation of isolated aortic rings. Heart Vessels 2011, 26, 549-556. [CrossRef]

41. Yamada, A.; Sakurai, T.; Ochi, D.; Mitsuyama, E.; Yamauchi, K.; Abe, F. Antihypertensive effect of the bovine casein-derived peptide Met-Lys-Pro. Food Chem. 2015, 172, 441-446. [CrossRef]

42. Flouris, A.D.; Schlader, Z.J. Human behavioral thermoregulation during exercise in the heat. Scand. J. Med. Sci. Sports 2015, 25, 52-64. [CrossRef] 
43. Schlader, Z.J.; Simmons, S.E.; Stannard, S.R.; Mündel, T. The independent roles of temperature and thermal perception in the control of human thermoregulatory behavior. Physiol. Behav. 2011, 103, 217-224. [CrossRef] [PubMed]

44. Schlader, Z.J.; Stannard, S.R.; Mündel, T. Evidence for thermoregulatory behavior during self-paced exercise in the heat. J. Therm. Biol. 2011, 36, 390-396. [CrossRef]

45. Amano, T.; Ichinose, M.; Inoue, Y.; Nishiyasu, T.; Koga, S.; Kondo, N. Modulation of muscle metaboreceptor activation upon sweating and cutaneous vascular responses to rising core temperature in humans. Am. J. Physiol. Regul. Integr. Comp. Physiol. 2015, 308, R990-R997. [CrossRef] [PubMed]

(C) 2020 by the authors. Licensee MDPI, Basel, Switzerland. This article is an open access article distributed under the terms and conditions of the Creative Commons Attribution (CC BY) license (http://creativecommons.org/licenses/by/4.0/). 